\title{
IMPROVEMENT OF ETHANOL PRODUCTION FROM YAM BEAN BY THERMO-TOLERANT YEAST Saccharomyces cerevisiae RMU Y-10 USING AN ORTHOGONAL ARRAY DESIGN
}

\author{
KITIPONG WECHGAMA ${ }^{1}$ AND KANLAYANI CHAROENSOPHARAT*2 \\ ${ }^{I}$ Department of Agricultural Technology and Environment, Faculty of Science and Liberal Arts, Rajamangala University \\ of Technology Isan, Nakhon Ratchasima, 30000, Thailand. ' Department of Biology, Faculty of Science and Technology, \\ Rajabhat Maha Sarakham University, 44000, Thailand.
}

*Corresponding author: chkanlayani@gmail.com

Submitted final draft: 15 December 2020 Accepted: 24 December $2020 \quad$ http://doi.org/10.46754/jssm.2021.02.004

\begin{abstract}
Nitrogen and minerals are essential for the growth of yeast and in metabolic pathways of ethanol fermentation. This research examined the effects of nitrogen and added minerals on ethanol production from yam bean juice by Saccharomyces cerevisiae RMU Y-10. Three factors affecting ethanol production efficiency i.e., yeast extract (YE) concentrations (3, 6 and $9 \mathrm{~g} / \mathrm{L}$ ), diammonium hydrogen phosphate (DAP) concentrations $(0.25,0.50$ and $0.75 \mathrm{~g} / \mathrm{L})$ and $\mathrm{MgSO}_{4}$ concentrations $(0.5,1.0$ and $1.5 \mathrm{~g} / \mathrm{l})$ were investigated using a $L_{9}\left(3^{4}\right)$ Orthogonal array design. Fermentation was performed at $37^{\circ} \mathrm{C}$ and $\mathrm{YE}$ showed the greatest influence on ethanol concentration followed by DAP and $\mathrm{MgSO}_{4}$. The highest ethanol concentration of $51.2 \mathrm{~g} / \mathrm{L}$, with yield $\left(Y_{p / s}\right)$ and productivity $\left(Q_{p}\right)$ values of 0.51 and $0.71 \mathrm{~g} / \mathrm{L} . \mathrm{h}$, respectively, was obtained under the optimal conditions of $9 \mathrm{~g} / \mathrm{L} \mathrm{YE}$, $0.75 \mathrm{~g} / \mathrm{L}$ DAP and $0.5 \mathrm{~g} / \mathrm{L} \mathrm{MgSO}_{4}$. The ethanol concentration obtained under the optimum conditions was about $30 \%$ higher than those obtained in control sets using YM medium or yam bean juice without nutrients added to the substrates.
\end{abstract}

Keywords: Ethanol production, yam bean, thermo-tolerant yeast, orthogonal array design.

\section{Introduction}

Bioethanol is a promising alternative fuel because it is clean, renewable and environmental friendly that can be made from plants containing high sugar and starch, such as sugarcane, potato and corn. The yam bean (Pachyrhizus erosus L. Urban) is a root crop in the Fabaceae family, also known as legumes. This plant has several advantages in terms of high nutritional value, ability to grow in poor soil and resistance to pests and diseases (Sørensen et al., 1994).

Yam bean is one of the potential feedstock for ethanol fermentation as it contains $90.07 \%$ water, $0.09 \%$ fat, $0.72 \%$ protein, $4.9 \%$ fiber, $8.82 \%$ carbohydrate and $1.8 \%$ sugar (USDA Agricultural research service, 2020). High temperature fermentation technology (HTFT) is a new technology with advantages like increased rate of catalytic reaction, reduced risk of of contamination and is energy-saving as it does not require a complex cooling system, besides having low operating expenses (Sootsuwan et al., 2007; Limtong et al., 2007).
However, the system needs a thermo-tolerant yeast strain capable of growing and producing ethanol at high temperatures. There are several species of ethanologenic yeast that have been characterized and identified as thermotolerant, namely Saccharomyces cerevisiae, Kluyveromyces marxianus and Pichia kudriavzevii (Charoensopharat \& Wechgama, 2019; Charoensopharat et al., 2015; Chamnipa et al., 2018). These strains can produce ethanol at temperatures ranging from $37^{\circ} \mathrm{C}$ to $45^{\circ} \mathrm{C}$. The efficiency of ethanol production depends on many factors, such as nitrogen and carbon sources, and divalent cations. Several investigators have reported that the ethanol tolerance and sugar utilization efficiency of $S$. cerevisiae may be improved by supplementing adequate nutrients in the fermentation medium (Appiah-Nkansah et al., 2018; Gomez-Flores et al., 2018; Phukoetphim et al., 2019). Supplementing fermentation medium with nitrogenous nutrients, such as ammonium salts, corn steep liquor, spent brewer's yeast and yeast 
extract, besides adding minerals such as calcium, magnesium, manganese, potassium and zinc, may enhance ethanol production by promoting the growth of yeast cells. Our previous study showed that available sugar, yeast extract and initial cell concentrations could affect ethanol fermentation from sugarcane molasses by $S$. cerevisiae RMU Y-10 (Charoensopharat \& Wechgama, 2019). However, in the process of ethanol production, the concentration and several types of nitrogen compounds and mineral elements must also be optimized to achieve the high values of ethanol concentration or volumetric ethanol productivity. This study aims to investigate ethanol production from yam bean juice under thermo-tolerant conditions. The influence of initial concentration of yeast extract (YE), diammonium hydrogen phosphate (DAP), and magnesium sulfate $\left(\mathrm{MgSO}_{4}\right)$ on ethanol production were also optimized by the statistical $L_{9}\left(3^{4}\right)$ Orthogonal array design.

\section{Materials and Methods}

\section{Microorganism and starter culture preparation}

The thermo-tolerant yeast $S$. cerevisiae RMU Y-10 was isolated and identified by Charoensopharat and Wechgama (2019). It was grown in $50 \mathrm{ml}$ of yeast malt medium (YM) in a $250 \mathrm{~mL}$ flask at $30^{\circ} \mathrm{C}$, and shaken at $150 \mathrm{rpm}$ for 16 to 18 hours. The $10 \%(\mathrm{v} / \mathrm{v})$ enriched cultures were transferred to YM broth $(10 \%$, w/v of glucose) and incubated at $30^{\circ} \mathrm{C}$ with shaking rate of $150 \mathrm{rpm}$ for six to eight hours before use as starter cultures for fermentation.

\section{Raw Material}

Yam beans were obtained from Borabue, Maha Sarakham province, Thailand. The yam bean juice was extracted by mechanical pressing and stored at $-20^{\circ} \mathrm{C}$.

\section{Ethanol production medium and batch ethanol production}

The Yam bean juice was supplemented with YE, DAP and $\mathrm{MgSO}_{4}$ at various concentrations according to the Orthogonal array design in Table 1. $4 \mathrm{~N} \mathrm{NaOH}$ was used to set the medium to $\mathrm{pH} 5$ before sterilization at $121^{\circ} \mathrm{C}$ for $15 \mathrm{~min}$. Batch fermentation was conducted at $37^{\circ} \mathrm{C}$ in airlocked flasks containing $250 \mathrm{ml}$ of fermentation medium.

\section{Orthogonal experimental design}

Table 1 shows an $L_{9}\left(3^{4}\right)$ Orthogonal array design. The three levels of variable factors, including YE concentrations $(A)(3,6$, and $9 \mathrm{~g} / \mathrm{L})$, DAP concentrations $(B)(0.25,0.50$, and $0.75 \mathrm{~g} / \mathrm{L})$, and $\mathrm{MgSO}_{4}$ concentrations $(C)(0.5,1.0$, and $1.5 \mathrm{~g} / \mathrm{L})$ were set. Ethanol concentrations were observed as a response. The experiments were

Table 1: Orthogonal array design $L_{9}\left(3^{4}\right)$ for three variables

\begin{tabular}{|c|c|c|c|c|c|}
\hline \multirow{2}{*}{ Run } & Factor $A$ & Factor B & Factor $C$ & Factor D & Response \\
\hline & YE (g/L) & $\operatorname{DAP}(\mathrm{g} / \mathrm{L})$ & $\mathrm{MgSO}_{4}(\mathrm{~g} / \mathrm{L})$ & Blank & $P($ Ethanol, g/L) \\
\hline 1 & 9 & 0.75 & 0.50 & (level 2) & $51.20 \pm 0.3^{\mathrm{g}}$ \\
\hline 2 & 6 & 0.75 & 1.00 & (level 1) & $46.10 \pm 0.2^{\mathrm{d}}$ \\
\hline 3 & 3 & 0.25 & 0.50 & (level 1) & $40.30 \pm 0.4^{\mathrm{a}}$ \\
\hline 4 & 9 & 0.25 & 1.00 & (level 3) & $47.40 \pm 0.1^{\mathrm{e}}$ \\
\hline 5 & 3 & 0.50 & 1.00 & (level 2) & $40.10 \pm 0.3^{\mathrm{a}}$ \\
\hline 6 & 6 & 0.50 & 0.50 & (level 3) & $45.20 \pm 0.4^{\mathrm{c}}$ \\
\hline 7 & 9 & 0.50 & 1.50 & (level 1) & $48.30 \pm 0.4^{\mathrm{f}}$ \\
\hline 8 & 3 & 0.75 & 1.50 & (level 3) & $42.40 \pm 0.2^{\mathrm{b}}$ \\
\hline 9 & 6 & 0.25 & 1.50 & (level 2) & $45.20 \pm 0.5^{\mathrm{c}}$ \\
\hline
\end{tabular}

*Data in the same column are not significantly different according to Duncan's multiple tests at $95 \%$ confidence if marked with different superscript letters. All experiments were done in triplicates. The presented $P$ values are mean \pm SD 
conducted in triplicates. A blank factor was applied as a dummy variable for error evaluation. ANOVA was performed to estimate the effects of variable factors on ethanol concentration (Farzaneh et al., 2011).

\section{Analytical Methods}

Total soluble solids (TSS) of the fermentation medium were analyzed by a hand-held refractometer. Number of yeast cells in the fermentation broth was counted using a hemocytometer (Zoecklien et al., 1995). Total sugar concentration of the liquid sample was estimated using the phenol sulfuric acid method according to Dubois et al. (1956). The $\mathrm{pH}$ was determined using a $\mathrm{pH}$ meter. Concentration of ethanol in the sample was determined using gas chromatography with a flame ionization detector (Shimadzu, Kyoto, Japan) according to the method described by Laopaiboon et al. (2009). The yield of ethanol $\left(Y_{p / s}, \mathrm{~g} / \mathrm{g}\right)$ was defined as: $Y_{p / s}$ $=$ produced ethanol $(\mathrm{g}) /$ amount of sugar utilized (g), while volumetric ethanol productivity $\left(Q_{p}\right.$, $\mathrm{g} / \mathrm{L}$ hours $)=$ ethanol concentration $(P, \mathrm{~g} / \mathrm{L})$ / time of fermentation yielding the greatest ethanol concentration ( $t$, hours).

\section{Results and Discussion}

Ethanol fermentation from yam bean by $S$. cerevisiae RMU Y-10

The fermentation profile of Run 1 (YE; $9 \mathrm{~g} / \mathrm{L}$, DAP; $0.75 \mathrm{~g} / \mathrm{L}$, and $\mathrm{MgSO}_{4} ; 0.5 \mathrm{~g} / \mathrm{L}$ ) is shown in Figure 1, in which the $\mathrm{pH}$ value of the fermented broth decreased from 5.00 to 4.45 after 24 hours. The total sugar concentration decreased from $120 \mathrm{~g} / \mathrm{L}$ to $19.37 \mathrm{~g} / \mathrm{L}$ after 84 hours, and sugar utilization was about $100.63 \mathrm{~g} / \mathrm{L}$. The highest cell concentration $\left(8.58 \times 10^{7}\right.$ cells/ $\mathrm{ml}$ ) was counted at 60 hours of fermentation time. The concentration of ethanol increased with increasing fermentation time. Ethanol concentration $(P)$ was $51.2 \mathrm{~g} / \mathrm{L}$ at 72 hours and it corresponded to $Y_{p / s}$ and $Q_{p}$ at 0.51 and $0.71 \mathrm{~g} / \mathrm{L}$ hours respectively.

The fermentation profiles of other experimental runs showed a similar trend as the result of the experimental Run 1 (data not shown). At the end of fermentation, $P$ values ranging from $40.1 \mathrm{~g} / \mathrm{L}$ to $51.2 \mathrm{~g} / \mathrm{L}$ (Table 1) were observed, while the total sugar ranged from $120 \mathrm{~g} / \mathrm{L}$ to $19.73 \mathrm{~g} / \mathrm{L}$ and cell concentration ranged from $1.7 \times 10^{6}$ to $8.58 \times 10^{7}$ cells $/ \mathrm{ml}$. The final $\mathrm{pH}$ values of the fermentation broth were in the range of 5 to 4.38 . Different amounts of parameters affected ethanol fermentation efficiencies. Highest ethanol concentration was obtained from Run 1.

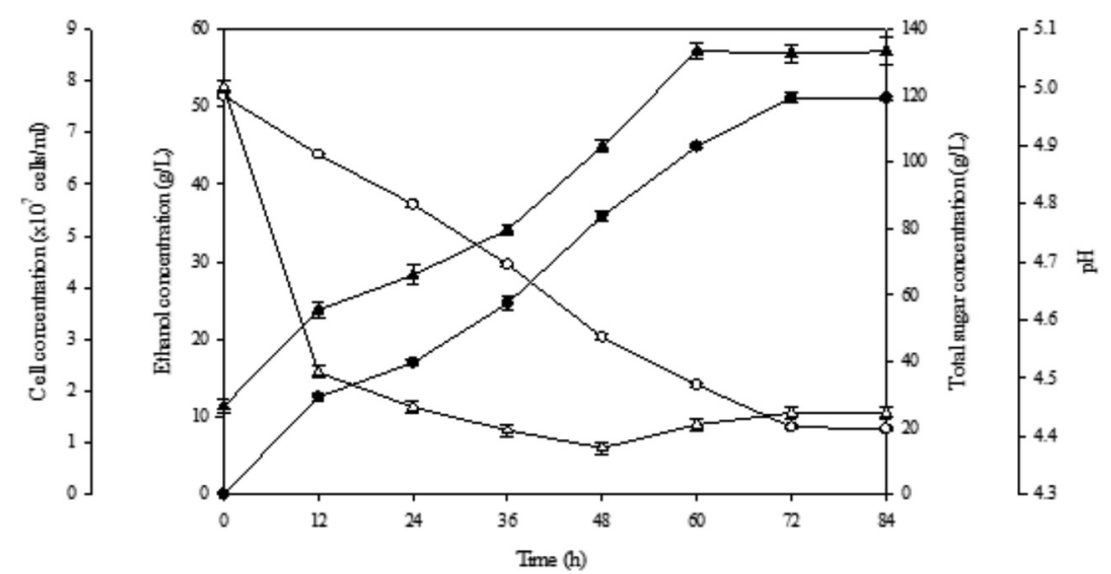

Figure 1: Profiles of batch ethanol fermentation from yam bean by S. cerevisiae RMU Y-10 in the experimental Run $1(\bullet$, ethanol; $\bigcirc$, total sugar; $\boldsymbol{\Delta}$, cell and $\Delta, \mathrm{pH})$ 
Nitrogenous compounds were necessary for cell growth as it affected the synthesis of protein, amino acids, nucleotides, volatile compounds and other metabolites of the microorganisms (Gobert et al., 2019). Ethanol concentrations increased with increasing YE concentrations, indicating that higher initial YE concentration was effective in significantly improving the kinetics of the fermentation process, permitting the reaction to reach its highest final ethanol titre and productivity. Nuanpeng et al. (2001) reported that when $9 \mathrm{~g} / \mathrm{L}$ YE were added into the ethanol production medium, the maximum ethanol concentration was achieved.

DAP could be used as phosphorus and nitrogen supplements to promote yeast growth and increase fermentation efficiency. A significant increase in ethanol concentrations was observed in the medium with increasing DAP concentrations. Phosphorus plays a major role in the glycolysis pathway of the yeast cell (Fadel et al., 2013).

The effect of $\mathrm{MgSO}_{4}$ on ethanol production medium had been investigated. The maximum ethanol concentration was achieved when the $0.50 \mathrm{~g} / \mathrm{L} \mathrm{MgSO}_{4}$ was supplemented into the medium. Magnesium has a major role in metabolic processes like glycolysis, enhancing physiological functions besides promoting cell growth and proliferation. Therefore, supplementation of magnesium in the fermentation medium at optimum concentration could subsequently enhance ethanol production efficiency (Walker, 1994).

\section{Optimization of Ethanol Concentrations}

The $L_{9}\left(3^{4}\right)$ Orthogonal array design was applied to evaluate three parameters i.e., YE, DAP, and $\mathrm{MgSO}_{4}$ concentrations at three levels. The range analysis of $L_{9}\left(3^{4}\right)$ experimental design for ethanol concentration $(P)$ is shown in Table 2.

\section{Impact of $\mathrm{YE}, \mathrm{DAP}$ and $\mathrm{MgSO}_{4}$ on Ethanol Concentration}

The range analysis was applied to evaluate the impact of YE (Factor A), DAP (Factor B) and $\mathrm{MgSO}_{4}$ concentrations (Factor $C$ ) on $P$ value. The $R$ value of the parameter indicated a higher impact on $P$ value. The values of $k$ were used to clarify the optimum level of each factor to promote the highest ethanol concentration. The concentration was influenced in the order of YE, DAP, and $\mathrm{MgSO}_{4}$ concentrations, and optimum levels of the factors were $A_{3} B_{3} C_{1}$, corresponding to $\mathrm{YE}$ at $9 \mathrm{~g} / \mathrm{L}, \mathrm{DAP}$ at $0.75 \mathrm{~g} / \mathrm{L}$ and $\mathrm{MgSO}_{4}$ at $0.5 \mathrm{~g} / \mathrm{L}$.

ANOVA was used to validate the order of the effects of these factors on ethanol

Table 2: The range analysis of $L_{9}\left(3^{4}\right)$ Orthogonal experiments of ethanol concentration

\begin{tabular}{cccc}
\hline & \multicolumn{3}{c}{$\boldsymbol{P}$ : Ethanol concentration $\mathbf{( g / L})$} \\
\hline$K_{1}$ & $\begin{array}{c}\text { YE } \\
(\mathbf{g} / \mathbf{L})\end{array}$ & $\mathbf{D A P}(\mathbf{g} / \mathbf{L})$ & MgSO $_{\mathbf{4}}(\mathbf{g} / \mathbf{L})$ \\
\hline$K_{2}$ & 122.8 & 132.9 & 136.7 \\
$K_{3}$ & 136.5 & 133.6 & 133.6 \\
$k_{1}$ & 146.9 & 139.7 & 135.9 \\
$k_{2}$ & 40.93 & 44.30 & 45.57 \\
$k_{3}$ & 45.50 & 44.53 & 44.53 \\
$R$ & 48.97 & 46.57 & 45.30 \\
$Q$ & 8.03 & 2.27 & 0.27 \\
\hline
\end{tabular}

Totality of levels 1,2 and 3 for each factor are designed as $K_{1}, K_{2}$ and $K_{3}$. Mean level scores 1, 2 and 3 for each factor are designed as $k_{1}, k_{2}$ and $k_{3} . R$ value is evaluated by the difference between the highest and lowest mean score $\left(k_{\max }-k_{\min }\right)$. $Q$ is the optimal value of each factor for ethanol fermentation. 
concentration (data not shown). In accordance with the $F$ values obtained in this study, order of influence $\left(F_{Y E}=157.11, F_{D A P}=15.04\right.$ and $F_{M g S O 4}$ $=2.78$ ) was a similar trend to the $R$ values. The $R^{2}$ value was $0.994316(99.43 \%)$. The ethanol concentration of $51.2 \mathrm{~g} / \mathrm{L}$ was obtained under the optimum condition (Run 1: $A_{3} B_{3} C_{1}$ ), which was very close to the response predicted $(50.83$ $\mathrm{g} / \mathrm{L}$ ). The results suggested that the model was valid in predicting the experimental results (Jangchud, 2006).

Figure 2 shows the change in ethanol concentrations with the variation of three parameters. The levels ethanol concentration elevated from $40.93\left(k_{l}\right)$ to $48.97\left(k_{3}\right) \mathrm{g} / \mathrm{L}$ when YE concentrations were increased from $3 \mathrm{~g} / \mathrm{L}$ to $9 \mathrm{~g} / \mathrm{L}$. The greatest ethanol concentration of $48.97 \mathrm{~g} / \mathrm{L}\left(k_{3}\right)$ was observed with $9 \mathrm{~g} / \mathrm{L}$ of YE. YE was an effective source of amino acids that contained lactose, adenine and trehalose, which were beneficial in promoting protein biosynthesis and cell growth (Gomez-Flores et al., 2018).

In the case of DAP concentrations, $S$. cerevisiae RMU Y-10 showed the highest ethanol concentration of $46.47 \mathrm{~g} / \mathrm{L}\left(k_{3}\right)$ with 0.75 $\mathrm{g} / \mathrm{L}$ of DAP. Seguinot et al. (2018) reported that DAP addition decreased ethanol fermentation time and increased the rate of fermentation. Additionally, a maximal ethanol concentration, $45.57 \mathrm{~g} / \mathrm{L}\left(k_{l}\right)$, was observed when $0.5 \mathrm{~g} / \mathrm{L}$ of $\mathrm{MgSO}_{4}$ was used.

The increasing amounts of $\mathrm{MgSO}_{4}$ in the fermentation medium did not enhance ethanol concentration. Similarly, Charoensopharat et al. (2015) found that supplementation of $\mathrm{MgSO}_{4}$ into the medium did not improve the capability of thermo-tolerant yeast $K$. marxianus DBKKU Y-102 in ethanol production at high temperatures. Their results implied that the fermentation medium they used Jerusalem artichoke tubers

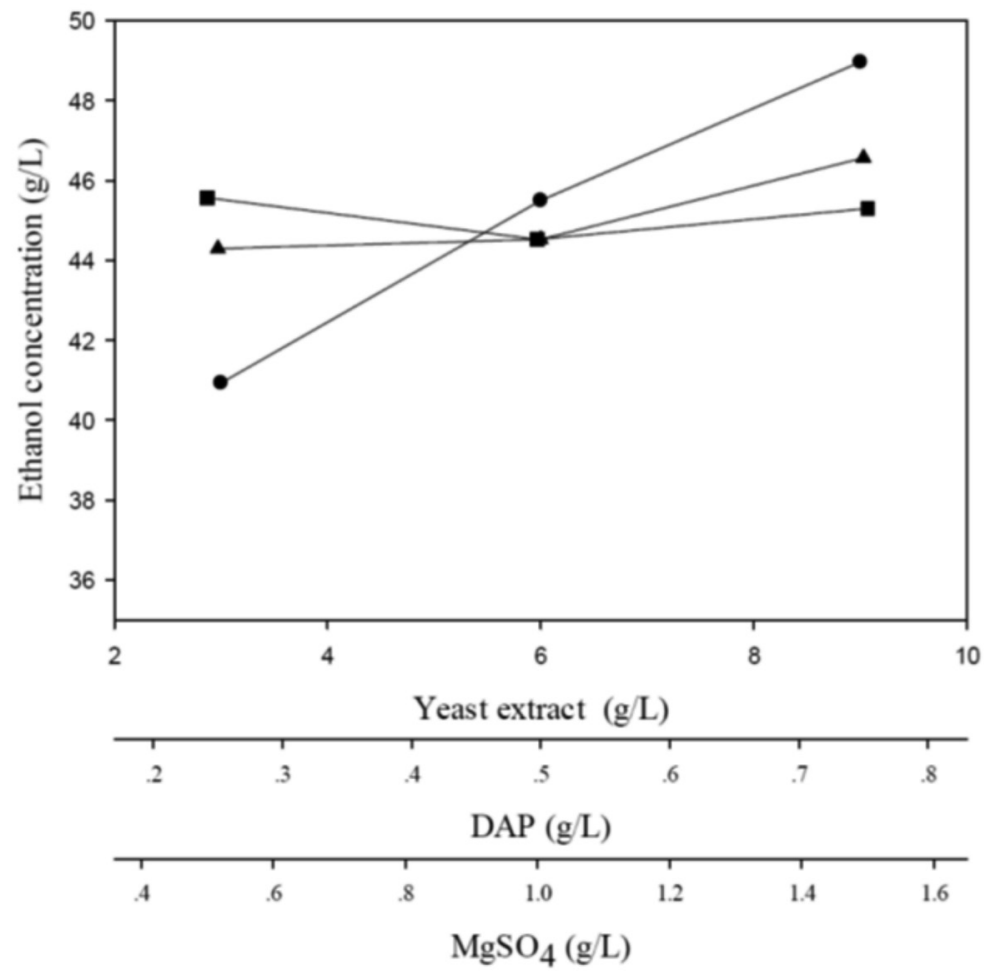

Figure 2: Impact of elevated levels and parameters on ethanol concentrations in an Orthogonal tested $(\bullet, \mathrm{YE}$; $\boldsymbol{\Delta}, \mathrm{DAP}$ and $\boldsymbol{\square}, \mathrm{MgSO}_{4}$ ) 
Table 3: Ethanol fermentation from yam bean by thermo-tolerant yeast $S$. cerevisiae RMU Y-10 under the optimal and control conditions

\begin{tabular}{lccc}
\hline \multirow{2}{*}{ Results of Fermentation } & $\begin{array}{c}\text { Optimal Condition } \\
\left(\text { Run } 1: \boldsymbol{A}_{3} \boldsymbol{B}_{3} \boldsymbol{C}_{1}\right)\end{array}$ & $\mathbf{1}$ & $\mathbf{2}$ \\
\cline { 3 - 4 } & $51.20 \pm 0.30^{\mathrm{b}}$ & $39.49 \pm 0.28^{\mathrm{a}}$ & $39.40 \pm 0.41^{\mathrm{a}}$ \\
Ethanol $(\mathrm{g} / \mathrm{L})$ & $100.63 \pm 0.85^{\mathrm{b}}$ & $80.52 \pm 0.57^{\mathrm{a}}$ & $81.2 \pm 0.37^{\mathrm{a}}$ \\
Sugar utilized $(\mathrm{g} / \mathrm{L})$ & 72 & 72 & 72 \\
Fermentation time (hours) & $0.51 \pm 0.00^{\mathrm{b}}$ & $0.49 \pm 0.00^{\mathrm{a}}$ & $0.49 \pm 0.00^{\mathrm{a}}$ \\
$Y_{p / s}$ & $0.71 \pm 0.00^{\mathrm{b}}$ & $0.55 \pm 0.00^{\mathrm{a}}$ & $0.55 \pm 0.01^{\mathrm{a}}$ \\
$Q_{p}(\mathrm{~g} / \mathrm{L}$ hours $)$ & $8.58 \pm 0.31^{\mathrm{b}}$ & $4.71 \pm 0.29^{\mathrm{a}}$ & $4.32 \pm 0.44^{\mathrm{a}}$ \\
Cell concentration $\left(10^{7}\right.$ cells/ml) & $4.54 \pm 0.02^{\mathrm{c}}$ & $4.21 \pm 0.01^{\mathrm{b}}$ & $4.16 \pm 0.01^{\mathrm{a}}$ \\
$\mathrm{pH}$ &
\end{tabular}

*Data in the same column are not significantly different according to Duncan's multiple tests at $95 \%$ confidence if marked with different superscript letters. All experiments were done in triplicates. All data are presented as mean \pm SD.

already had sufficient magnesium ions for the metabolic pathways of yeast growth.

YM medium and yam bean juice without nutrient addition were used as control sets designated as Control 1 and Control 2. As shown in Table 3, ethanol concentration was $51.20 \mathrm{~g} / \mathrm{L}$ under optimum conditions at 72 hours corresponding to $Y_{p / s}$ and $Q_{p}$ at 0.51 and 0.71 $\mathrm{g} / \mathrm{L}$ hours, respectively. Ethanol concentrations from control 1 and control 2 were $39.49 \mathrm{~g} / \mathrm{L}$ and $39.40 \mathrm{~g} / \mathrm{L}$, respectively, at the fermentation time of 72 hours. Results showed that ethanol concentrations obtained under the optimum condition were $30 \%$ greater than those obtained in control sets.

\section{Conclusion}

This study demonstrated the statistical optimization of different parameters for ethanol production from yam bean juice by thermotolerant yeast $S$. cerevisiae RMU Y-10. Yam beans could be a potential crop for ethanol production due to its low price and ease of growth in all kinds of soil. Yam bean juice containing $9 \mathrm{~g} / \mathrm{L}$ of YE, $0.75 \mathrm{~g} / \mathrm{L}$ of DAP and 0.5 $\mathrm{g} / \mathrm{L}$ of $\mathrm{MgSO}_{4}$ might potentially be used as an ethanol fermentation medium since it promoted optimum level of the ethanol production. The $L_{9}$ $\left(3^{4}\right)$ Orthogonal array design could be employed as a valuable tool to minimize the numbers of experiment and provide the complete information on all factors that affected ethanol production.

\section{Acknowledgements}

We like to thank Dr. Theeraphan Chumroenphat and staff at the Laboratory Equipment Center of Mahasarakham University, Thailand, for their help in providing lab facilities.

\section{References}

Appiah-Nkansah, N. B., Zhang, K., Rooney, W., \& Wang, D. (2018). Ethanol production from mixtures of sweet sorghum juice and sorghum starch using very high gravity fermentation with urea supplementation. Industrial Crops \& Products, 111, 247253248.

Chamnipa, N., Thanonkeo, S., Klanrit, P., \& Thanonkeo, P. (2018). The potential of the newly isolated thermo-tolerant yeast Pichia 
kudriavzevii RZ8-1 for high-temperature ethanol production. Brazilian Journal of Microbiology, 49, 378-391.

Charoensopharat, K., \& Wechgama, K. (2019). Effect of initial cell, yeast extract and sugar concentrations on ethanol production from molasses by thermo-tolerant yeast Saccharomyces cerevisiae RMU Y-10. AsiaPacific Journal of Science and Technology, 24(02), 1-7.

Charoensopharat, K., \& Wechgama, K. (2019). Enhancement of ethanol production from acid-hydrolyzed cassava starch by thermotolerant yeast Saccharomyces cerevisiae RMU Y-10 using an orthogonal array design. EAU Heritage Journal Science and Technology, 13(2), 2019 May - August, 100-114.

Charoensopharat, K., Thanonkeo, P., Thanonkeo, S., \& Yamada, M. (2015). Ethanol production from Jerusalem artichoke tubers at high temperature by newly isolated thermo-tolerant inulin utilizing yeast Kluyveromyces marxianus using consolidated bioprocessing. Antonie van Leeuwenhoek, 108, 173-190.

Dubois, M., Gilles, K. A., Hamilton, J. R., Robers, P. A., \& Smith, F. Colourimetric Method for Determination of Sugar and Related Substances. (1956). Analytical Chemistry, 28, 350-356.

Fadel, M., Keera, A. A., Mouafi, F. E., \& Tarek Kahil1. (2013). High level ethanol from sugar cane molasses by a new thermotolerant Saccharomyces cerevisiae strain in industrial scale. Biotechnology Research International, 2013, 1-6.

Farzaneh, A., Ehteshamzadeh, M., \& Mohammadi, M. (2011). Corrosion performance of the electroless Ni-P coatings prepared in different conditions and optimized by the Taguchi method. Journal of Applied Electrochemistry, 41, 19-27.
Gobert, A., Tourdot-Maréchal, R., Sparrow, C., Morge, C., \& Alexandre, H. (2019). Influence of nitrogen status in wine alcoholic fermentation. Food Microbiology, $83,71-8572$.

Gomez-Flores, R., Thiruvengadathan, T. N., Nicol, R., Gilroyed, B., Morrison, M., Reid, L. M., \& Margaritis, A. (2018). Bioethanol and biobutanol production from sugarcorn juice. Biomass and Bioenergy, 108, 455463.

Jangchud, A. (2006). Product optimization In Statistics for product development and application. Kasetsart University, Bangkok.

Laopaiboon, L., Nuanpeng, S., Srinophakun, P., Klanrit, P., \& Laopaiboon, P. (2009). Ethanol production from sweet sorghum juice using very high gravity technology: Effects of carbon and nitrogen supplementations. Bioresource Technology, 100(18), 41764182.

Limtong, S., Sringiew, C., \& Yongmanitchai, W. (2007). Production of fuel ethanol at high temperature from sugar cane juice by newly isolated Kluyveromyces marxianus. Bioresource Technology, 98, 3367-3374.

Nuanpeng, S., Laopaiboon, L., Srinophakun, P., Klanrit, P., Jaisil, P., \& Laopaiboon, P. (2011). Ethanol production from sweet sorghum juice under very high gravity conditions. Electronic Journal of Biotechnology, 14, 1.

Phukoetphim, N., Chan-u-tit, P., Laopaiboon, P., \& Laopaiboon, L. (2019). Improvement of bioethanol production from sweet sorghum juice under very high gravity fermentation: Effect of nitrogen, osmoprotectant, and aeration. Energies, 12, 3620.

Seguinot, P., Rollero, S., Sanchez, I., Sablayrolles, J. M., Ortiz-Julien, A., Camarasa, C., \& Mouret, J. R. (2018). Impact of the timing and the nature of nitrogen additions on the production kinetics of fermentative aromas by Saccharomyces cerevisiae during 
winemaking fermentation in synthetic media. Food Microbiology 76, 29-39.

Sootsuwan, K., Irie, A., Murata, M., Lertwattanasakul, N., Thanonkeo, P., \& Yamada, M. (2007). Thermo-tolerant Zymomonas mobilis: comparison of ethanol fermentation capability with that of an efficient type strain. The Open Biotechnology Journal, 1, 59-65.

Sørensen, M. Adjahossou, D. F. D. J. M., Annerose, A., Arévalo T., Estrella, E. J., Grum, M., Heredia, G. E., Halafibi, M., Morera, J. A., Nielsen, P. E., Stölen, O., \& Vieira da Silva, J. (1994). The YAM bean project: A pan-tropical evaluation of the tuber-bearing legume (genus Pachyrhizus
DC). Proceedings of the Tenth Symposium of the International Society for Tropical Root Crops, held in Salvador, Bahia, Brazil, October 23-29.

USDA U. S. Department of agriculture agricultural research service. (2020). Yam bean (jicama), raw. Retrieved from https:// fdc.nal.usda.gov/fdc-app.html\#/fooddetails/170073/nutrients.

Walker, G. M. (1994). The roles of magnesium in biotechnology. Critical Reviews in Biotechnology, 14, 311-354.

Zoecklein, B. W., Fugelsang, K. C., Gump, B. H., \& Nury, F .S. (1995) Wine Analysis and production. New York: Chapman \& Hall. 
winemaking fermentation in synthetic media. Food Microbiology 76, 29-39.

Sootsuwan, K., Irie, A., Murata, M., Lertwattanasakul, N., Thanonkeo, P., \& Yamada, M. (2007). Thermo-tolerant Zymomonas mobilis: comparison of ethanol fermentation capability with that of an efficient type strain. The Open Biotechnology Journal, 1, 59-65.

Sørensen, M. Adjahossou, D. F. D. J. M., Annerose, A., Arévalo T., Estrella, E. J., Grum, M., Heredia, G. E., Halafibi, M., Morera, J. A., Nielsen, P. E., Stölen, O., \& Vieira da Silva, J. (1994). The YAM bean project: A pan-tropical evaluation of the tuber-bearing legume (genus Pachyrhizus
DC). Proceedings of the Tenth Symposium of the International Society for Tropical Root Crops, held in Salvador, Bahia, Brazil, October 23-29.

USDA U. S. Department of agriculture agricultural research service. (2020). Yam bean (jicama), raw. Retrieved from https:// fdc.nal.usda.gov/fdc-app.html\#/fooddetails/170073/nutrients.

Walker, G. M. (1994). The roles of magnesium in biotechnology. Critical Reviews in Biotechnology, 14, 311-354.

Zoecklein, B. W., Fugelsang, K. C., Gump, B. H., \& Nury, F .S. (1995) Wine Analysis and production. New York: Chapman \& Hall. 